\title{
仙台市内の民間賃貸借り上げ仮設住宅での被災者の入居プロセスと居住実態 MOVING PROCESSES AND CONDITIONS OF RESIDENTS UNDER THE HOUSING LEASE PROGRAM FOR DISASTER VICTIMS IN SENDAI CITY
}

\author{
新井信幸*, 米野史健** \\ Nobuynki ARAI and Fumitake MENO
}

\begin{abstract}
Following the Great East Japan Earthquake, the housing lease program for disaster victims supplied over 60,000 private rental houses that serve as temporary housing. The number of houses has exceeded the number of newly constructed units of prefabricated temporary housing and many residents moved to urban areas in order to acquire rental houses. To examine moving processes and living conditions of residents under this program, an interview survey was conducted with residents living in leased houses in Sendai City. The following results were obtained. (1) Residents who were able to acquire housing in the early stage found rental houses with the cooperation of relatives and acquaintances, instead of real estate agents. (2) Many residents were not able to acquire adequate houses for the number of persons in their households. For this reason, families had to live separately. (3) Some residents experienced stress with their new life in rental houses because of the drastic change in their living environment.
\end{abstract}

Keywords : Temporary Housing, Private Rental Housing, Housing Lease Program for Disaster Victims, the Great East Japan Earthquake 応急仮設住宅，民間賃貸住宅，借り上げ仮設住宅制度，東日本大震災

\section{1. 研究の背景と目的}

東日本大震災では、応急仮設住宅の新規建設のほか、借り上げ仮 設住宅・みなし仮設住宅・応急借上げ住宅などと言われる、民間賃 貸住宅の借り上げも実施されている。借り上げ仮設住宅の大規模な 実施は今回の震災が初めてで、全国計で最大 68597 戸 (2012 年 4 月 3 日時点）が供給され、応急仮設住宅の新規建設や公営住宅等の提 供戸数を超えている。

膨大な量の借り上げのため制度の運用では様々な混乱や問題が生 じており、行政の記録で実態や課題が報告されているほか 112)3)、こ れらを踏まえた今後の対応も手引きの形で示されている ${ }^{4)}$ 。これら の供給側からの把握・検討に対し、需要側である被災者の実態は十 分に把握できていない。先行調査として福島県 ${ }^{5)}$ ・仙台市 ${ }^{677)}$ ・釜石 市 ${ }^{8)}$ でのアンケート結果の報告があり、世帯や入居の全体的な状況 は示されているが、物件の確保方法や入居後の生活状況等の実態は 明らかではない。将来起きうる災害時における借り上げ仮設住宅の 適切な運用策を考える上では、供給側のみならず需要側からの検討 を行い、被災者の生活の安定と再建の促進という応急仮設住宅の本 来的な役割の観点から評価し総合的に判断することが求められ、そ のための個別具体の入居状況の実態把握が必要となる。

そこで本研究では、借り上げ仮設住宅が最も多く供給された宮城 県仙台市を対象に、個別の世帯に着目して、入居のプロセスと居住 及び生活の実態を詳細に明らかにし、課題を把握・検討することを 目的とする。

* 東北工業大学工学部建築学科 准教授 ·博士 (学術)

** 国土交通省国土技術政策総合研究所

防災・メンテナンス基盤研究センター建設経済研究室 主任研究官·博士 (工学)

\section{2. 研究の方法}

入居のプロセスと居住及び生活の実態に関しては、多数を対象に したアンケート調査では、設問数の制限や多様な事情を反映した選 択肢設定の困難さ、及び自由記述回答による限界等もあり、十分な 情報を把握することは難しい。よって、個々の世帯毎のヒアリング によって詳細な状況を聞き取ることが求められる。

しかし、個別の物件及び入居世帯に関する情報は、契約主体の県 や支援を行う市町村は把握しているものの、一般には公開されてい ない。建設型のプレハブ仮設住宅とは異なり、一般の民間賃貸住宅 等に分散しているため、その存在を独自に把握することは難しい。

そこで、筆者らが支援活動を行う仙台市内の津波被災地区におけ る復興まちづくりの現場で、借り上げ仮設住宅の居住世帯に調査へ の協力を求めるとともに、知人等の紹介を受ける形で、計 11 世帯を 把握・選定した。あわせて、上記方法で生じる可能性のある調査対 象者の偏りを出来るだけ補正するため、筆者が参画した仙台市内の 借り上げ仮設住宅居住者へのアンケート調查注 1)で、「今後行うヒア リング調查に協力してもよい」と回答し連絡先を記した者の中から、 前記 11 世帯とは従前居住地や世帯構成、物件特性等が異なる 9 世帯 を選定し、合計 20 世帯を調査対象とした。

前者 11 世帯は 2012 年 8 12 月、後者 9 世帯は 2013 年 $2 \sim 3$ 月に かけて、世帯主または準ずる人への 1 世帯あたり 1 時間半程度のヒ アリング調查を行い、世帯の状況、入居に至るまでのプロセス、入 居物件の概要、及び入居及び生活上の課題等を把握した。 


\section{3. 宮城県及び仙台市における借り上げの概要}

先行調查報告 ${ }^{23} 3$ ) 9 ) 等に基づき借り上げの運用状沉を概括する。 県では、建設型の仮設住宅の補完として民間賃貸住宅の借り上げ を実施するとし、不動産業界団体との事前協定に基づき物件の情報 を把握し、4月 8 日付で取扱を各市町村に通知した。また 4 月 15 日 に仙台を中心に物件を借り上げ、民間賃貸住宅支援室を設置し募集 を行った。これは従来の震災でも行われた一般的な手順であるが、 物件と希望者のマッチングが困難で入居は進まなかった。

このような状況を受け、被災者が自ら探した物件も借り上げの対 象とするよう運用が変更され、4月 30 日付の厚生労働省の通知で特 例措置が正式に示されたのを受けて、5月 13 日付で改めて取扱を通 知し、募集が行われた。仙台市では 4 月 27 日より受付を開始し、既 に契約し居住する場合は「切替契約」として既契約を一度終了して 県・貸主・入居者の 3 者契約に切り替える形で、新たに入居寸る場 合は「新規契約」として 3 者契約を結ぶ形で、手続が進められた。

\section{4. 世帯と入居の概況}

対象世帯の状況と入居の経緯を [表 1] に、入居物件の概要を [図 1 ]に示す。対象世帯は入居日順に A〜T の記号で表している。

\section{(1) 世帯の状況}

世帯主の年齢は、 50 歳代 8 人、60 歳代 5 人、70 歳代 4 人、 20 • 30 ・40 歳代がそれぞれ 1 人で、平均 58.7 歳である。

現在働いている世帯主は 13 人で、建設業 3 人、会社員 2 人のほか、 多岐にわたる職業がみられる。このうち 10 人は震災前後で職が变わ っていない。震災を機に変わっているのは 4 人で、後述する居住地 の移動に伴う転職 2 人 (R, S ) のほか、同じく居住地を移動した後に 働き始めた人（M)、農業を営んでいたが働かなくなった人（L)がみ られる。現在無職の 7 人のうち、農業を辞めた 1 人以外は震災前も 無職であり、年齢が 60 歳代以上であることから既に退職していたも のとみられる。

世帯類型は、単身 5 件、夫婦のみ 2 件、夫婦十未婚の子供 6 件、三 世代 4 件、その他 3 件である。世帯の人数は平均 2.9 人で、 65 歳以 上の高齢者がいる世帯は 12 件ある。借り上げ仮設住宅の入居時や入 居後に世帯分離が起きているのは 11 件で、分離した人数を足した震 災前の世帯人数は平均 4.0 人となり、世帯の小規模化が確認される。
これらの状況について仙台市内の借り上げ仮設居住者アンケート 調査 $^{(1)}$ の結果をみると、世帯主の平均年齢は 55.7 歳で就業者は $67.0 \%$ 、世帯人数は平均 2.63 人で高齢者がいる世帯は $29.7 \%$ であ り、世帯主の特徵はそう変わらないが、世帯の規模は本調查の方が 大きく、高齢者も含む大家族の対象者が多いといえる。

\section{(2) 入居の状況}

従前の居住地は、仙台市沿岸部 11 件、仙台市内陸部 2 件、仙台市 外 7 件である。前述の通り仙台市内の復興まちづくりの関係者が主 な対象のため、津波被害を受けた沿岸部が中心である。仙台市内の 計 13 件のうち、同じ区内に入居したのは 6 件である。仙台市外の 7 件では、 2 件は近接する市町（七ヶ浜町、名取市）から、それ以外 は気仙沼市・南三陸町・石巻市各 1 件と遠方からの転入である。

入居の時期は、 2011 年 3 月が 5 件、 4 月 4 件、 5 月 3 件、 6 月 2 件、 7 月 2 件、 8 月 3 件、 9 月 1 件で、仙台市内にプレハブ仮設住宅 が設置され始めた 5 月頃までに 12 件、 6 月以降に 8 件が入居してい る。5 月までの早期入居 11 世帯のうち仙台市内沿岸部からの入居が 9 件を占めており、逆に 6 月以降の入居 8 世帯のうち仙台市外の遠 方からの入居世帯は 4 件で半数を占めており、市外からの転入の方 が遅くなっている。世帯規模も 5 月までの入居世帯は平均 3.3 人な のに対し、6 月以降の世帯は平均 2.3 人であり、早期入居の方が世 帯人数は多くなっている。

入居する物件については、12 件では親類や知人等を介して探され ており、このうち 10 件は 5 月までの早期入居分である。また、親類 や知人が家主である物件への入居は 8 件、うち 6 件は早期入居分で あり、早期入居の多くは親類・知人に頼っている状況がみられる。 一方、物件探しが遅かった世帯では、希望の地域で空室を見つけら れず、後述するように物件探しが難航している（N, $0, P, R, T) 。$

\section{(3) 入居物件}

集合住宅 16 件、戸建住宅 4 件である。集合住宅では 2 階建が 10 件で 6 割強を占め、 5 階以上の中高層は 3 件のみである。中高層が 少ないことから、構造では RC, SRC 造は 7 件のみで、木造が 8 件で最 も多く、S 造も5 件みられる。これより、低層のいわゆるアパート タイプの物件が主要な入居先になっていることが確認される。

築年数は 3 年から 45 年までと幅広いが、年数の分かった 17 件中 では、10 年未満は 4 件のみ、30 年以上が 7 件で、比較的古い物件が

表 1 調査対象世帯の状況と入居に関する概要

\begin{tabular}{|c|c|c|c|c|c|c|c|c|c|c|c|c|c|c|}
\hline \multirow[b]{2}{*}{ 帯 } & \multicolumn{4}{|c|}{ 世帯主 } & \multicolumn{4}{|c|}{ 世帯の状況 } & \multicolumn{2}{|c|}{ 居住地 } & \multicolumn{3}{|c|}{ 入居の経緯 } & \multirow[b]{2}{*}{$\begin{array}{l}\text { 調査 } \\
\text { 実施 }\end{array}$} \\
\hline & $\begin{array}{l}\text { 年 } \\
\text { 齢 }\end{array}$ & \begin{tabular}{|l|} 
性 \\
別
\end{tabular} & $\begin{array}{l}\text { 従前 } \\
\text { 職業 }\end{array}$ & $\begin{array}{l}\text { 現在 } \\
\text { 職業 }\end{array}$ & 人 & $\begin{array}{l}\text { 世帯 } \\
\text { 類型 }\end{array}$ & $\begin{array}{c}\text { 世帯主以外の世帯員 } \\
\text { ()内は年齢 }\end{array}$ & $\begin{array}{c}\text { 世帯分離した者 } \\
\text { ()内は年齢 }\end{array}$ & 従前 & 現在 & \begin{tabular}{|c|} 
入居 \\
日
\end{tabular} & 仲介者 & 家主 & \\
\hline A & 50 後 & 男 & 建馀 & 没業 & 5 & 三世代 & 妻(50前) $)+$ 息子(20後 $)+$ 娘(20後) + 母(80前) & (再建後に娘が分離) & 若林区荒浜 & 太白区砂押 & $3 / 15$ & 親類 & 親類 & $\mathrm{H} 24.10$ \\
\hline $\mathrm{B}$ & 60前 & 男 & 無 & 職 & 2 & 夫婦 & 凄(60前) & & 若林区荒浜 & 泉区黒松 & $3 / 16$ & 親類 & 親類 & H24.10 \\
\hline $\mathrm{D}$ & 60後 & 男 & & 職 & 6 & 三世代 & 妻(50後)+娘(20後)+息子(20後)+息子妻 $(20$ 後)+孫(3) & 息子(20後) & 七ヶ浜町 & 泉区鶴ヶ丘 & $3 / 25$ & 知人·不動産店 & & $\mathrm{H} 25.2$ \\
\hline $\mathrm{E}$ & 50後 & 男 & 公可 & 茖員 & 4 & 三世代 & 妻 $(50$ 後 $)+$ 娘 $(20$ 後 $)+$ 母(70後) & 息子(20後) & 若林区荒浜 & 若林区沖野 & $3 / 26$ & 不動産店 & & $\mathrm{H} 24.11$ \\
\hline $\mathrm{F}$ & 50 後 & 男 & 運融 & 送業 & 4 & 三世代 & 妻(50前) + 娘 $(10$ 前 $)+母(70$ 後) & 息子+息子妻+子2 & 若林区荒浜 & 太白区東中田 & $4 / 1$ & JA·不動産店 & & H24.11 \\
\hline $\mathrm{G}$ & 40後 & 男 & 電気 & 工事業 & 5 & 夫婦+子 & 妻(40前)+息子(10前)+息子(10前)+娘(4) & 父+母 & 若林区荒浜 & 若林区一本杉町 & $4 / 13$ & 知人.不動産店 & & H24.10 \\
\hline $\mathrm{H}$ & 50 後 & 男 & 自 & 営業 & 3 & その他 & 妻 $(50$ 後 $)+$ 母(70後) & 息子(20後) & 若林区荒浜 & 太白区八木山東 & $4 / 22$ & 知人 & 知人 & H24.10 \\
\hline I & 50 前 & 男 & 製文 & 告業 & 4 & 夫婦+子 & 妻(30後)+息子(10後)+娘(10後) & 母(80後)、息子(10後) & 若林区荒浜 & 青葉区宮町 & $4 / 28$ & 会社·不動産店 & & H24.10 \\
\hline $\mathrm{J}$ & 70前 & 女 & 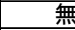 & 職 & 1 & 単身 & & & 気仙沼市松崎 & 太白区砂押 & $5 / 3$ & 親類 & 親類 & H24.10 \\
\hline $\mathrm{K}$ & 60 後 & 男 & 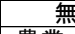 & 職 & 1 & 単身 & & & 名取市閖上 & 太白区富沢 & $5 / 10$ & 知人.不動産店 & 知人 & $\mathrm{H} 25.2$ \\
\hline $\mathrm{L}$ & 70前 & 女 & 農業 & 無職 & 1 & 単身 & & 息子(40後) & 若林区三本塚 & 太白区南大野田 & $5 / 22$ & 親類 & 親類 & H24.8 \\
\hline$M$ & 70後 & 男 & \begin{tabular}{|c|l} 
無職 \\
\end{tabular} & 建設業 & 2 & 夫婦 & 凄(70後) & & 南三陸町志津川 & 太白区南大野田 & $6 / 1$ & 不動産店 & & $\mathrm{H} 25.2$ \\
\hline $\mathrm{N}$ & 20後 & 男 & 会神 & 社員 & 3 & 夫婦+子 & 妻+子 & 父+母+祖母 & 若林区荒浜 & 太白区袋原 & $6 / 1$ & 不動産店 & & $\mathrm{H} 25.3$ \\
\hline 0 & 50前 & 男 & 自宫 & 燈業 & 3 & 夫婦+子 & 妻(50前)+息子(20後) & 娘(20後)+子(4)、母 & 若林区荒浜 & 若林区中倉 & 7月頃 & 知人 & 知人 & H24.10 \\
\hline$P$ & 60 後 & 女 & 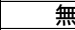 & 職 & 1 & 単身 & & & 石巻市門脇 & 宮城野区田子 & $7 / 25$ & 不動産店 & & H25.2 \\
\hline Q & 70後 & 男 & $\begin{array}{l}\text { 無 } \\
\end{array}$ & 職 & 3 & 夫婦+子 & 妻(70前) $)^{\text {息子(40後) }}$ & & 泉区七北田 & 泉区泉中央 & $8 / 1$ & 知人(不動産店) & 知人 & $\mathrm{H} 25.2$ \\
\hline $\mathrm{R}$ & 50前 & 男 & 会社員 & 会社員 & 2 & その他 & 母(70後) & & 気仙沼市幸町 & 太白区富沢 & $8 / 7$ & 不動産店 & & $\mathrm{H} 25.2$ \\
\hline
\end{tabular}


多い。ケース C のように老朽化が進んでいるとみられる物件もある。 立地では駅からの所用時間の回答が得られた 13 件のうち、利便性の 低い徒歩 15 分以上が 6 件である。間取りは $2 \mathrm{~K}$ から $5 \mathrm{DK}$ まで多様で あり、入居した人数とは概ね対応しているようである。家賃は平均 6.5 万円で、最小 3.5 万円〜最大 14.0 万円となっている。

なお、震災前の住宅に関しては、賃貸よりは持家、集合住宅より は戸建住宅が多くなっており、間取りは3DK〜 7LDK などで二世帯住 宅もあり、借り上げ仮設住宅と比べるとより広い傾向がみられる。

\section{5. 入居のプロセス}

被災直後から避難を経て借り上げ仮設住宅へ入居し現在（調查時 点）に至る過程に関し、いつどこで暮らしたかとその際の世帯構成 を整理したのが［図 2］である。

(1) 被災から避難

災害発生は平日昼間だったため家を離れていた者が多く、在宅の 家族や別途外出していた家族とは、自宅近隣の学校等の避難所で、

当日夜または翌日に合流している場合が中心となっている。避難所 を使わずに直接親類宅に移った者（E)、車内で避難した者もいるほ か $(\mathrm{P}, \mathrm{T}) 、$ 半壊の自宅で暮らし続けた者もみられる $(\mathrm{Q})$ 。

(2) 避難から借り上げ仮設住宅入居まで
避難所から直接借り上げ仮設住宅に移ったのは 2 件（A, K ）、被災 した自宅から借り上げ仮設に移ったのは 2 件（Q, T) で、その他の 16 件では学校・公民館等の公的施設や親類宅等への移動を繰り返し ている。それと同時に家族が合流と分離を繰り返す様子もみられる。

全体の傾向として、親類宅に身を寄せる間に借り上げ仮設住宅を 探す形であり、前述の通り仲介者が親類・知人で家主も親類・知人 のケースが多く、既存の人間関係を活用して居場所が確保されてい る。仙台市外から市内借り上げ仮設に入居した 7 件のうち、3 件は 市内の親族宅に移ってからの入居で（J, M, R)、その他は市外から直 接転入している（D, K, P, S)。

なお、被災者が自ら探した物件も借り上げる特例措置（4月30日 の厚労省通知) の運用前とみられる 5 月上旬までの入居は 11 件で $(\mathrm{A}$ 〜 K)、これらでは後に切替の手続が行われており、切替の時期は 5 月から 9 月まで様々である。

借り上げ仮設住宅への入居の際に、避難時に分離していた世帯が 同居した場合が 4 件 (A, I, L, M) ある一方、世帯分離が起こった場合 が 5 件みられる。世帯の分離は、避難段階の分離がそのまま継続 (D) の他は、三世代世帯が世代毎に分離する形(F, G, N, 0) となっている。 (3) 借り上げ仮設住宅の入居後

入居後の世帯変化は 6 件みられる。子供の進学 $(H, I)$ や結婚に伴

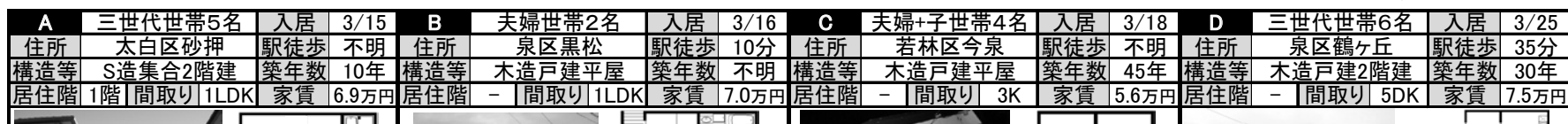

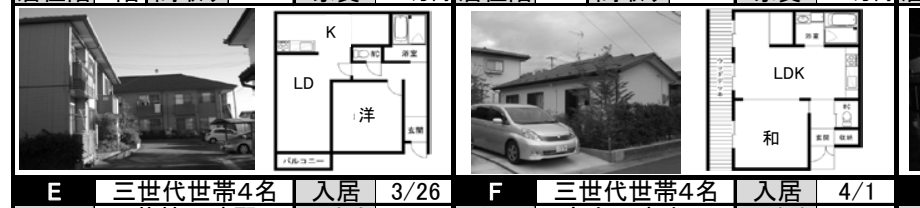

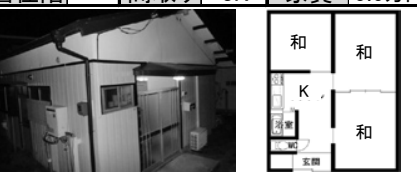
In (is.

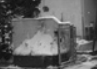
和 和

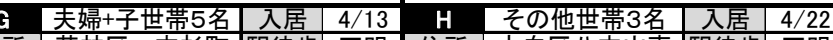

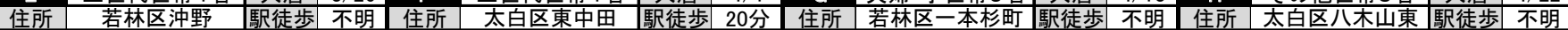

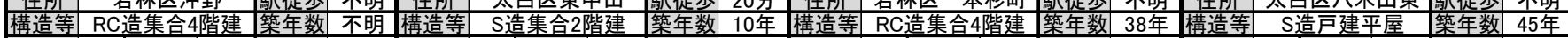

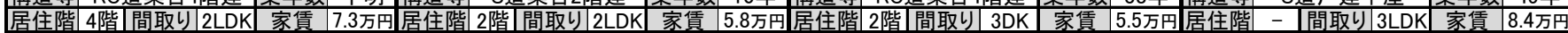

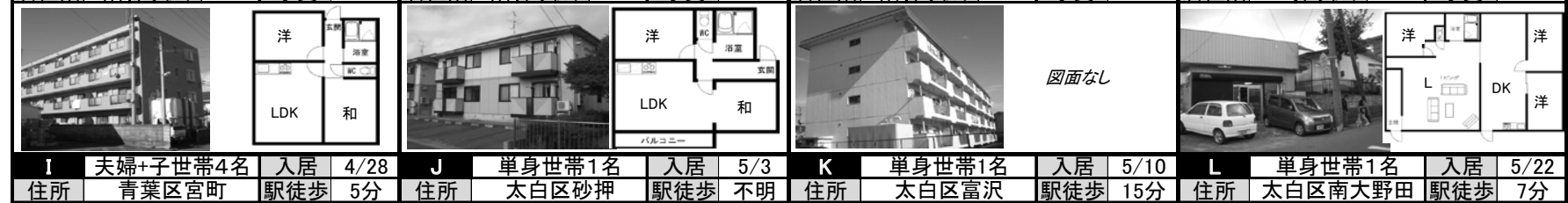

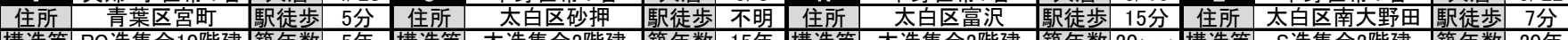
構造等 $R C$ 造集合 10 階建 築年数 5 年 構造等 木造集合2階建 築年数 15 年 構造等 木造集合2階建 築年数 20 年以上構造等 S造集合2階建 築年数 20 年

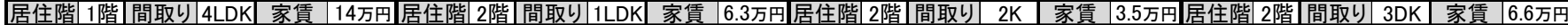

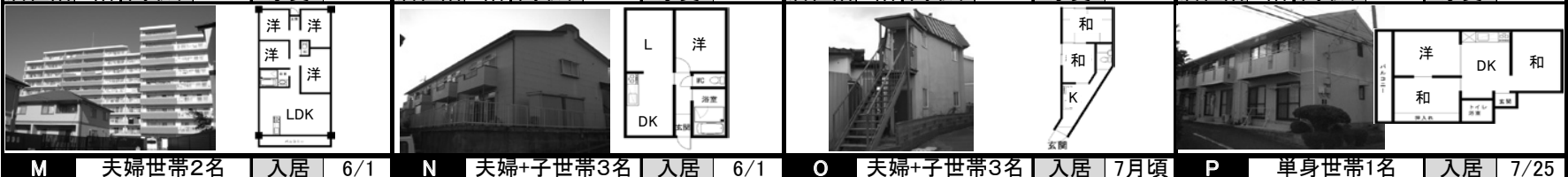

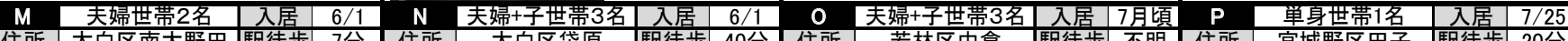

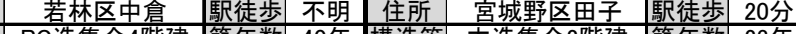
構造等 S造集合2階建 築年数 不明 構造等 RC造集合2階建 築年数 3 年 構造等 RC造集合4㫮建 築年数 40 年 構造等 木造集合2階建 築年数 23 年

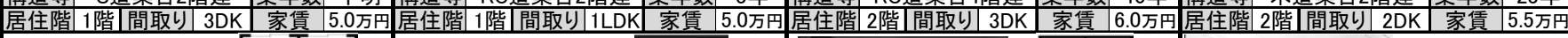

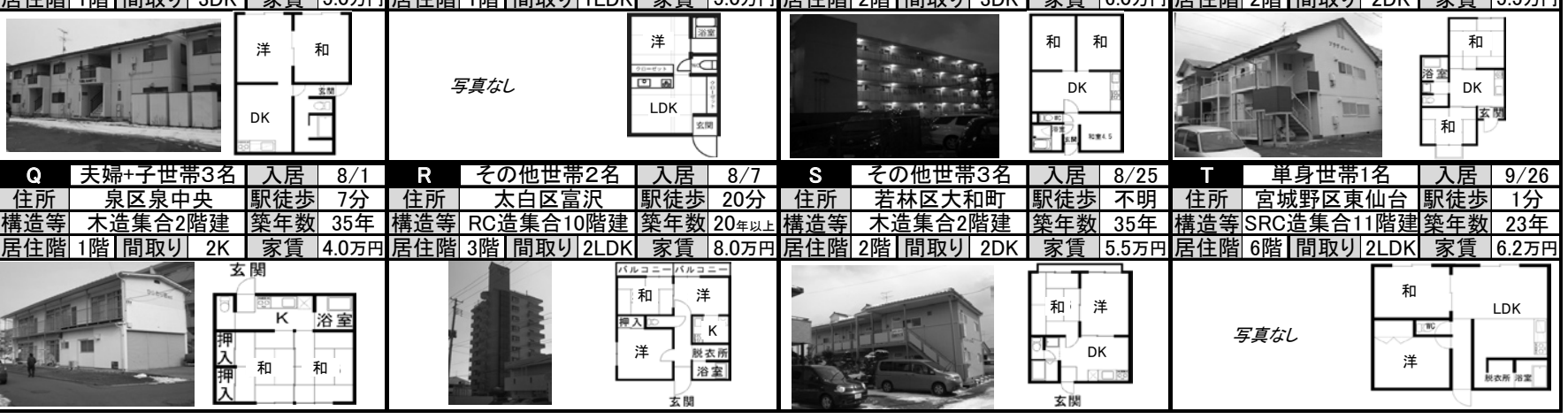

図 1 調査対象世帯が入居した借り上げ仮設住宅の物件概要 
う独立（L）の他は、住宅の狭さから子世代が別居（C, E)、生活環境 の問題から親世代が転居（A, I）と、三世代世帯の分離である。

\section{6. 入居及び居住における課題・問題}

ヒアリングで語られた各種の課題・問題を、借り上げ仮設の入居 まで、入居後の住環境面、及び生活環境面の 3 つに分けて整理した のが［表 2］である。

(1) 借り上げ仮設に入居した理由

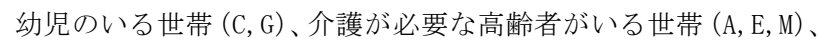
体調に不安のある家族がいる世帯 (B, I) では、避難所等での生活が 困難なため、借り上げ仮設を希望し、多くはプレハブ仮設住宅が完 成し始めた 5 月より前に入居している。一方で、ペットがいるため 避難生活が困難で迷惑をかける、あるいは原則ペット禁止のプレハ
ブ仮設住宅には入れないとの理由から、戸建ての借り上げ仮設住宅 等に入居したケースもある（D, K, 0)。

市外からの転入世帯では、従前地域ではみつからず物件が多い仙 台市内で探した $(\mathrm{P}) 、$ 仕事を探すため仙台に来た（R, S ) ケースがあ る。前述のペット問題でも、地元ではペット可物件がないため仙台 に移っている (D, K)。

\section{(2) 入居における問題点}

物件探しが困難だったと 20 世帯中 9 世帯（D, I, K, N, O, P, R, S, T) が答えている。単身高齢者であることやペットを飼育していること で家主等から入居を拒まれるケース (D, K) のほか、借り上げ制度自 体を不動産店に敬遠されるケースもある（S）。一方、従前の住宅と 同じ形態で慣れ親しんだ環境であることと、ペットの飼育も考慮し て、戸建住宅を求めるケースもみられるが（R）、市場に戸建物件が

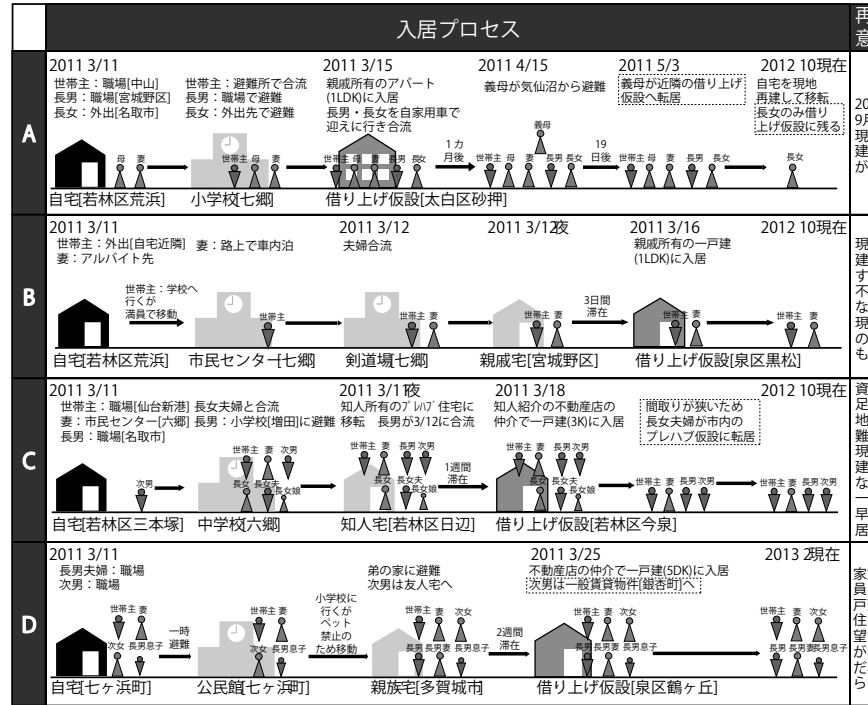

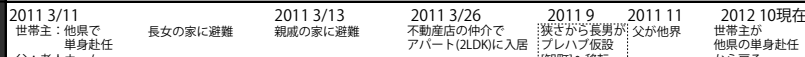

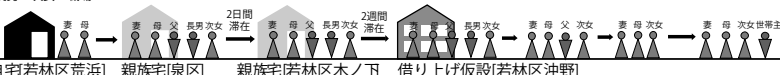

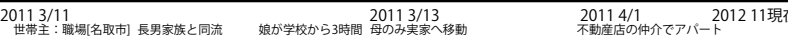

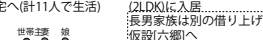

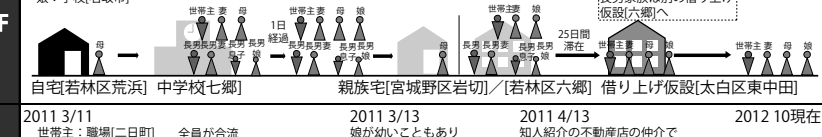

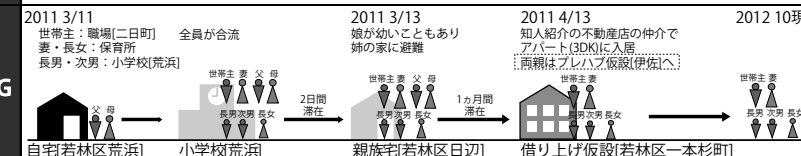

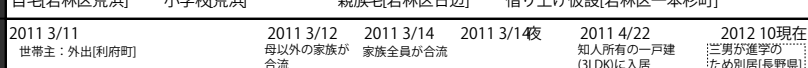

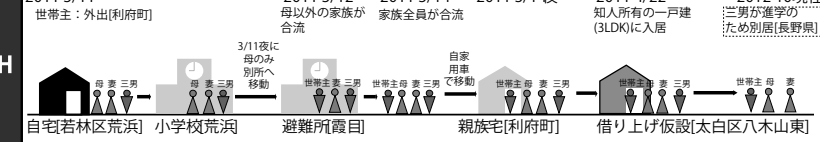

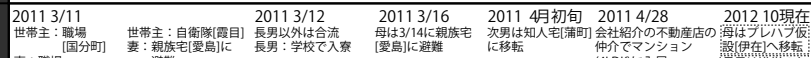

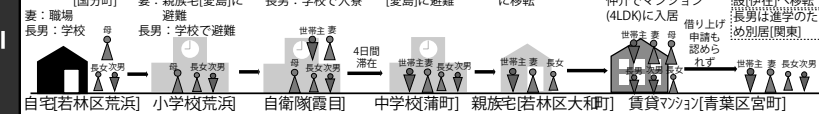

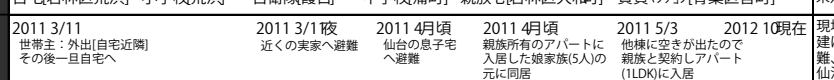

鐿建

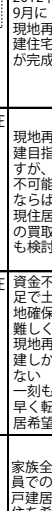

入居プロセス

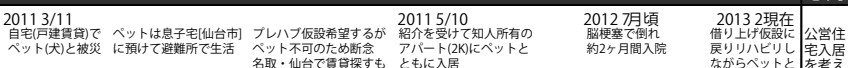

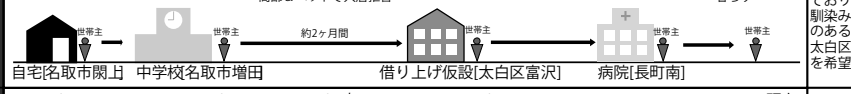

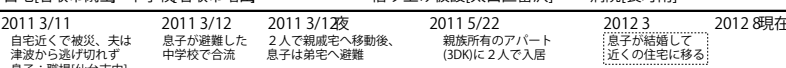

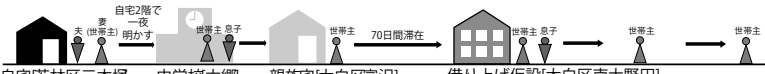

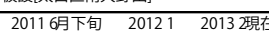

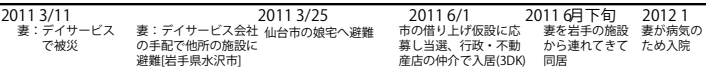

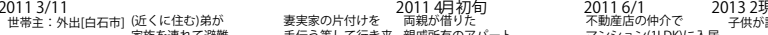

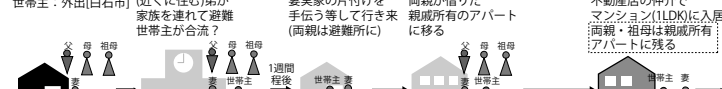

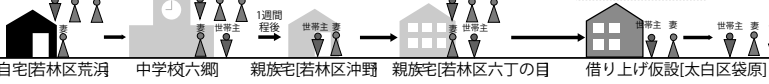

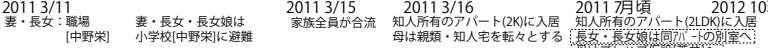

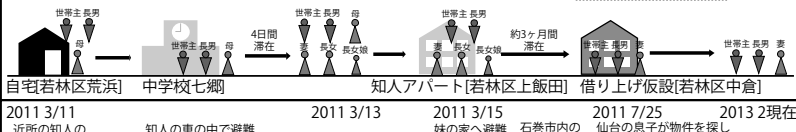

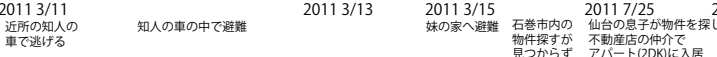

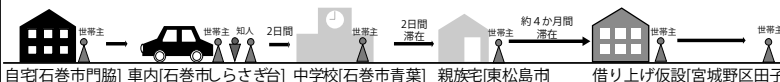
20116月末 20132現左

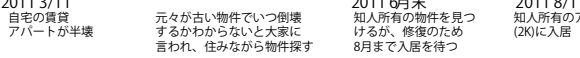

\section{A}

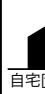

自宅湶区地批

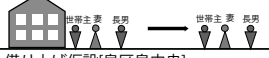

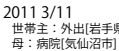

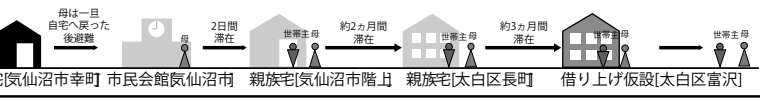

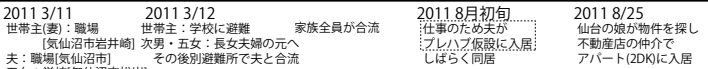


少ないことから探し出すのに苦労している。

\section{(3) 入居後の住環境の評価}

世帯人数に対して間取りが狭いと感じている世帯が 20 世帯中 8 世帯みられる (A, C, D, E, F, G, I, N, 0)。従前の住宅が広い戸建住宅で あった世帯が多いことが影響していると考えられ、このため一住戸 での生活が難しく入居後に子世代が別居した例もみられる（C,E）。 また建物や設備の老朽化（K, P）や、バリアフリー非対応（M, R） のため、不便な暮らしを強いられているケースもある。こうしたな か、戸建住宅に入居した後に家主（知人）の了解を得て自費でリフ オームしたケースもみられている（H）。

\section{(4) 生活環境の変化に伴う問題}

入居してから健康等の状況が悪化の傾向にある世帯がみられる。 散歩や外出する機会が減ったことで、足が不自由になったり（H, R） 糖尿病を患ったり（B)している。また環境の変化が要因と思われる、 アレルギーや不眠症の発症 $(H, P) 、$ 体調悪化による入院 (M) の他、亡 くなる $(\mathrm{J})$ ケースもある。従前の農漁村部の戸建とは異なる街中の集 合住宅に入居したことで、畑での土いじりやガーデニングが出来な い $(\mathrm{L}, \mathrm{P}, \mathrm{R})$ 、部屋が狭くプライバシーが低い $(0)$ 、交通騒音が気に なる（S）として、ストレスを感じている世帯も少なくない。また、 以前の近隣関係から離れたため、近所づきあいが少ない、周りに知 人が少ないことで寂しさを感じる人もいる（B, I, L, M, P, R)。なお入 居時及び入居後に親世代が分離したケースでは、従前の人間関係の 継続を希望してプレハブ仮設を選んだ状況もみられている $(\mathrm{G}, \mathrm{I}, 0)$ 。

\section{7. 住まい再建への意向}

今後の再建意向は [図 2] の右端の項に示す。従前地での再建希 望が 7 件 (A, B, C, E, F, H, L)、移転等での持家再建希望が 5 件
(D, G, I, 0, T) で、このうち再建済が 1 件 (A)、計画進行中が 2 件 (E, F) ある。しかし、金銭面の負担が大きい等の理由から実現は難しいと 考える世帯も 2 件みられる（G, I)。また、現地再建が難しければ入 居中の借り上げ仮設住宅の買い取りを検討する世帯が 2 件 (B, H) あ り、いずれも親類・知人所有の戸建物件である。

一方、災害公営住宅への入居希望は 6 件で、寸べて仙台市外から の転入世帯である（J, K, M, P, R, S)。従前地に戻りたいとの希望もみ られるが (J, M, ) 、自力再建は難しいため仙台市内の災害公営住宅を 希望する形である。入居先としては、生活に慣れた現住地の近く、 あるいは親類・知人がいる地域を希望する者が多い。

入居時期別に再建意向をみると、早期に入居した A J の 10 世帯 中災害公営住宅希望は 1 件で、それ以降に入居した $\mathrm{K} \sim \mathrm{T}$ の 10 世帯 では災害公営住宅希望は 5 件であった。早期の入居世帯は借り上げ 制度の実施確定前に家顀の自己負担も想定して入居した世帯が多い とみられ、一定の経済力があり自立度が高いことから、自力再建を 志向しているものと推察される。

\section{8.入居プロセス及び居住実態の特徵的パターンと典型事例}

以上の状況を踏まえれば、入居プロセス及び居住実態にみられる 共通的な特徵として、次の 3 種類のパターンが提示出来る。

(1)地域内で早期入居も世帯分離が発生したパターン（A, C, D, E, F, G) 市内及び近隣市から、3 月 4 月中旬の比較的早期に入居したが、 親類や知人を頼って応急的に住宅を選択したため、間取り等の環境 面について十分吟味ができず、世帯構成と間取りのミスマッチが発 生し、入居時または入居後に世帯分離が生じている。

このうち事例 C は、発災後地元の中学校に避難したが、長女夫婦

表 2 入居に至る過程及び入居後の住環境・生活環境に関する課題・問題点

\begin{tabular}{|c|c|c|c|}
\hline 世帯 & 入居に際しての課題·問題点 & 住環境の課題·問題点 & 生活環境の変化に伴う課題·問題点 \\
\hline A & *母が認知症で介護必要なため避難所生活が困難 & *世帯人数(5人)に対して間取り(1LDK)が狭い & ·特になし(以前から知っている地域であった） \\
\hline B & *世帯主が過去に大手術しておりプレハブは避けたい & ··特になし(リフォーム済であり居住環境は良い) & $\begin{array}{l}\text { *上り坂多く散歩等が出来ないため妻が糖尿病に } \\
\text { *近所付き合いが全くないので叔しい }\end{array}$ \\
\hline C & $\begin{array}{l}\text { *娘の子供が当時生後2ヶ月で避難所生活が困難 } \\
\text { *物件選ぶ余裕なく人数(7人)に合わない間取り(3K)に }\end{array}$ & $\begin{array}{l}\text { *人数(7人)に対し間取り(3K)が狭く、入居後に娘家族(3人)が } \\
\text { プレハブ仮設に移り世帯分離が発生 } \\
\text { *結露がひどい/収納がない/脱衣スペースがない }\end{array}$ & -特になし(便利な場所で、近所に知り合いも多い) \\
\hline D & $\begin{array}{l}\text { *多数の不動産店回つたがペット可物件が見つからない } \\
\text { *間取りが行政の目安以上のため手続に手間を要する }\end{array}$ & $\begin{array}{l}\text { *人数(7人)に対し間取り(5DK)が狭く、息子1名が他の民間賃 } \\
\text { 貸に入居し世帯分離が発生 }\end{array}$ & $\begin{array}{l}\text { *買い物等は若干不便 } \\
\text { *犬を放して遊ぶスペースはない }\end{array}$ \\
\hline $\mathrm{E}$ & *父が要介護認定で避難所生活は困難 & $\begin{array}{l}\text { *人数(最大6人)に対し間取り(2LDK)が狭く、入居後に息子1 } \\
\text { 名がプレハブ仮設に移り世帯分離が発生 }\end{array}$ & $\begin{array}{l}\text { *集合住宅生活の経験がない母が不満覚える } \\
\text { ·入居後に父が他界 }\end{array}$ \\
\hline G & $\begin{array}{l}\text { *娘が小さく息子の中学入学もあり避難所生活は困難 } \\
\text { *物件探すが希望に合う物件はなかなか見つからず }\end{array}$ & $\begin{array}{l}\text { *人数(7人)に対し間取り(3DK)が狭く、両親が世帯分離 } \\
\text { *以前の戸建てと比べて住環境が悪い }\end{array}$ & $\begin{array}{l}\text { *住環境が悪くストレスかかるため家族関係が悪化 } \\
\text { *祖父母に見られる意識がなくなり子供の生活が変化 }\end{array}$ \\
\hline $\mathrm{H}$ & *物件を探すが家賃が高く入居出来ない[借り上げ適用前] & $\begin{array}{l}\text {-入居時に直己負担でリフォームを実施 } \\
\text {-住右務所を同敷地内で合わせて確保 }\end{array}$ & $\begin{array}{l}\text { *空気が悪く本人・妻がアレルギーになる } \\
\text { *母が運動不足になり足が不自由になる }\end{array}$ \\
\hline I & $\begin{array}{l}\text { *避難所で家族全員が病気にかかり長期生活は困難に } \\
\text { *社宅扱いで借りたため借り上げ申請が認められず、別物件 } \\
\text { 探すが見つからないため断念 }\end{array}$ & $\begin{array}{l}\text { *人数(6人)に対し間取り(4LDK)が狭く、入居後に母がプレハ } \\
\text { ブ仮設に移り世帯分離が発生 }\end{array}$ & 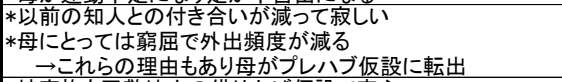 \\
\hline J & -特になし（親族所有の物件に入居） & ·特になし (一人なので間取りはちようどよい) & $\begin{array}{l}\text { ·娘家族も同敷地内の借り上げ仮設で安心 } \\
\text { *慣れない土地なので夜間の体調不良時に不安感じる }\end{array}$ \\
\hline $\mathrm{K}$ & $\begin{array}{l}\text { *ペツトがいるだめプレハブ仮設入居を断念 } \\
\text { *名取市で物件探すが高齢単身+ペットのため入居拒否を受 } \\
\text { ける、諦めて仙台市で探すが入居可能物件みつからず }\end{array}$ & $\begin{array}{l}\text { *老朽化激しくて浴室寒く、ヒートショックの心配があって家で } \\
\text { は風呂に入れていな }\end{array}$ & -特になし(近所付き合いないがペットがー緒で叔しくはない) \\
\hline L & ·特になし(親族所有の物件に入居) & |·入居後に息子が転居したのでー人では広すぎる & $\begin{array}{l}\text { *畑などでの土いじりが出来ずストレスがたまる } \\
\text { *近所付き合いがないので叔しい } * \text { 外出頻度が減る }\end{array}$ \\
\hline M & $\begin{array}{l}\text { *妻が認知症で介護必要なため志津川での生活困難 } \\
\text { ·市の借り上げ制度に募し当選したので件探し不要 }\end{array}$ & で妻の介護が大変 & $\begin{array}{l}\text { - 妻が通院していた仙台市内の病院に行く際は便利 } \\
\text { *周辺に友人がおらず寂しい } * \text { 入居後に妻が入院 }\end{array}$ \\
\hline $\mathrm{N}$ & $\begin{array}{l}\text { *紼介され見に行つた物件が既に埋まっていた } \\
\text { *間取りの希望あるも合致する物件見つからず諦める }\end{array}$ & *入居人数(3人)に対し間取り(1LDK)はやや狭い & -特になし \\
\hline 0 & $\begin{array}{l}\text { *ペツトがいるため避難所生活が出来ない } \\
\text { *物件探すが数が少なく見つけることが出来ない }\end{array}$ & $\begin{array}{l}\text { *人数(6人)に対し間取り(2LDK)が狭く、娘·孫は同建物の別 } \\
\text { 室に、母はプレハブ仮設に入居し世帯分離が発生 }\end{array}$ & *戸建に慣れており狭さやプライバシーの面でストレスたまる \\
\hline $\mathrm{P}$ & *石巻市内の物件探すが見つからない & *水回りの設備が老朽化しておりたびたび修理が必要 & $\begin{array}{l}\text { *近所付き合いがなく寂しい *外出の機会は大きく減少 } \\
\text { *交通騒音のため眠れず通院して薬の処方受けする } \\
\text { *趣味のガーデニングが出来ずストスがたまる }\end{array}$ \\
\hline Q & $\begin{array}{l}\text { ·特になし(不動産店·家主に知人おり物件探しは容易) } \\
\text { *震災で椇傷しており修理終了まで1ヶ月待つ }\end{array}$ & $* 10$ 年以上空室だった古い物件 & ·特になし(住み慣れた土地で生活変わらない) \\
\hline $\mathrm{R}$ & $\begin{array}{l}\text { *気仙沼では仕事みつからないため仙台で探す } \\
\text { *住み慣れた戸建を探すが物件少なくてみつからず }\end{array}$ & *手摺がなく取り付けも出来ないので不便 & $\begin{array}{l}\text { *母の足が不自由になり外出困難、精神的に塞ぎがちで神経 } \\
\text { 痛も悪化し通院 *周りに知り合いがおらず叔しい } \\
\text { *趣味のガーデニングが出来ないのが残念 }\end{array}$ \\
\hline $\mathrm{S}$ & $\begin{array}{l}\text { *気仙沼では任事みつからないため仙台で探す } \\
\text { *(娘が探すが借り上げ仮設希望と言うと動産店から何度 } \\
\text { も貨し渋られる、不動産店により対応が異なる }\end{array}$ & ·特になし & *交通騒音に慣れるまでに時間がかかる \\
\hline$T$ & *物件探しが遅れただ空室がほとんどなかった & ·特になし(希望の間取りを優先して探した) & ·特になし(希望の立地条件を優先して探した) \\
\hline
\end{tabular}


に生後 2 ケ月の子どもがおり避難所での生活は困難であったため、 その日のうちに知人所有のプレハブ小屋に移り、さらに別の知人を 通して不動産店の紹介を受け、3 月 18 日に従前地に近い戸建住宅 （3K）に入居した。その時点の世帯人数は 7 人で間取りとのミスマ ッチは顕著であったため、長女家族は 6 月に市内に設置されたプレ ハブ仮設住宅に転居し、現在は 4 人での生活となっている。

(2)避難が長期化し遅れて入居したパターン（I, K, L, N, 0)

市内及び近隣市からの入居だが、時期は 4 月下旬以降で一定の時 間を要している。入居までは親族・知人宅に身を寄せる（I, L, N, 0) か避難所で生活 (K) しており、前者の親族宅の場合には複数箇所に 分散するなど一時的な世帯分離も生じている。これらでは、物件を 探し始めるのが遅くなったため、あるいはペット飼育可（K）などの 条件があったため、空き室の確保が困難な状況がみられている。

このうち事例 N は、発災後は家族 5 人で避難所に滞在したが、妻 が妊娠中のため世帯主夫婦は 1 週間後に妻の実家に移り、祖母と両 親はその後も避難所に 1 ケ月程滞在した。4 月上旬に親類から無償 で借りたアパートに一家で入居したが、狭いこともあり世帯主夫妻 は物件探しを始めた。しかし条件に合う物件がなく、不動産店の紹 介やネットで見つけた空き物件が既に入居済など、苦労している。6 月 1 日に現住居へ入居し、誕生した息子と 3 人で暮らしている。 (3)遠方からの移転で入居が遅れたパターン（J, M, P, R, S）

気仙沼や南三陸等の遠方から仙台市内に転居した世帯で、複数の 避難先を経由した上で 5 月以降に入居している。仙台市内の親類宅 に身を寄せた後に同市内で物件を確保するケース（J, M, R）のほか、 地元 (石巻)で確保できなかったので仙台市内で探した世帯 (P)、仕 事を求めて仙台にきた世帯（S）もみられる。

このうち事例 R は、入院中の病院で被災した高齢の母親と避難所 で 2 日間過ごしたが、体調の不安等から地元気仙沼市の親類宅に身 を寄せており、間借りが長期化し母親の体調も悪化したため 5 月 3 日に仙台市内の次男宅に移った。その後不動産店を通して物件を探 し、病院に近い等の希望に合う物件がなく苦労したが、8月 7 日に 現住居に借り上げ仮設として入居した。入居出来たものの、従前の 住まいと環境が異なり身近に知り合いも少ないため外出が減り、母 親の神経痛が悪化し脚も不自由となっている。

\section{9. 結論}

上述の分析結果を整理したうえで借り上げ仮設住宅の課題を考察 し、今後の対応の在り方について展望する。

(1) まとめ・考察

(1)入居の時期により入居プロセスに違いがみられた。プレハブ仮設 完成前の 5 月までの入居世帯は、不動産仲介業者よりも親類や知人 を頼って物件を探し、応急的に民間賃貸住宅や戸建空き家に入居し ていた。しかしその場合は物件内容を吟味できず、世帯規模と間取 りのミスマッチが高い割合で生じ、結果的に世帯分離の発生につな がる場合もみられた。一方で物件探しが遅くなった世帯は、既に空 室が少ない状態のなかで物件確保に苦慮しており、そのため沿岸の 他市町から賃貸物件の多い仙台市へ転入するものも出ていた。 (2)世帯の特性によって入居状況に違いがみられた。幼児や高齢者等 の要配慮者がおり避難所生活が困難であった世帯では、物件を早期 に確保して移転していた。単身高齢者やペットを飼育する世帯も、
同様に避難所からの早期移転を望むが、家主等から入居を拒まれる ケースがみられた。

(3)入居後に健康面等の状況が悪化するケースがみられた。農漁村部 から市街地一、広い戸建住宅から狭い集合住宅へといった物理的環 境の変化とともに、世帯分離による家族の変化や地域社会との断絶 といった人間関係の変化が影響しているとみられる。また、因果関 係は定かでないが、入院や死亡に至る場合もあった。

\section{(2) 今後の対応のあり方}

(1)世帯規模と間取りのミスマッチやそれに伴う世帯分離が起きてお り、世帯状況に見合った物件の確保が求められる。災害直後のマッ チングが難しければ、入居後により適当な環境や条件の物件への移 転を認めることも必要であろう。または、緊急的段階に避難所を補 完する役割と応急的段階に仮設住宅を補完・代替する役割に分けて 運用し、応急的段階一の移行時に転居を可能にする形も考えられる。 (2)物件探しの困難さを解消寸るとともに、入居後の新しい環境への 順応を贲ポートする仕組みが求められる。例えば、民間賃貸住宅一 の円滑な入居の促進を図るために実施する居住支援協議会注 2) のよ うな制度を活用していくことが考えられる。

\section{謝辞}

本調査は、東北工業大学の中井弘道氏・佐藤寿亮氏 $\cdot$ 前田晃氏、 パーソナルサポートセンターの菅野拓氏・遠藤総子氏・螧原祥文氏、 地域・研究アシスト事務所の四井恵介氏と共同で実施した。ご協力 いただいた世帯の方々とともに、記して感謝の意を表する。

\section{注}

注 1）一般社団法人パーソナルサポートセンターが 2012 年 $2 \sim 3$ 月に行った 調查 6) で、同団体が以前に実施した生活支援物資（布団等）の提供に応募 があった市内の借り上げ仮設住宅居住者への郵送配布・回収で実施してい る(配布 2581, 回収 1369, 回収率 53. 0 \%)。

注 2) 住宅確保要配慮者（低額所得者、被災者、高齢者、障害者、子供を育 成する家庭その他特に配慮を要する者）の民間貸貸住宅への円滑な入居の 促進を図るため、地方公共団体や関係業者、居住支援団体等が連携（住宅 セーフティネット法第 10 条第 1 項）し、住宅確保要配慮者及び民間賃貸住 宅の賃貸人の双方に対し、住宅情報の提供等の支援を実施するものである。

\section{参考文献}

1) 岩手県県土整備部建築住宅課：東日本大震災津波対応の活動記録〜岩手県 における被災者の住宅確保等のための 5 か月間の取組み, 2011

2) 宮城県: 東日本大震災一宮城県の 6 か月間の災害対応とその検証, 2012

3) 仙台市: 東日本大震災 仙台市 震災記録誌～発災から 1 年間の活動記録～, 2013

4) 国土交通省・厚生労働省 : 災害時における民間賃貸住宅の活用について一 被災者に円滑に応急借上げ住宅を提供するための手引き，2012

5) 社団法人全国賃貸住宅経営協会：3.11 東日本大震災に学ぶ「我が国の新た な被災者支援のあり方」一応急仮設住宅の主軸となった民間賃貸住宅借上 げ制度と今後の課題, 2011

6)一般社団法人パーソナルサポートセンター : 仙台市内の仮設住宅入居世帯 の被災 1 年後の状態と将来像, 2012

7) 米野史健 : 仙台市内の応急仮設住宅としての民間賃貸住宅の借り上げにお ける入居の実態一東日本大震災 1 年後の借り上げ仮設住宅居住者へのアン ケート調查より, 日本建築学会計画系論文集, 日本建築学会, 第 78 卷第 689 号, pp. 1589-1596, 2013.7

8) 釜石市民の暮らしと復興についての意識調查・調查実施グループ : 釜石市 民の暮らしと復興についての意識調查（第 2 回）基本報告書， 2012

9) 式王美子 : 応急仮設住宅としての民間賃貸住宅借上げ制度にみる家賃支援 型住宅施策の論点一宮城県仙台市・多賀城市を事例に, 都市住宅学 79 号, pp. $105-110,2012.10$ 